\title{
Impact of relative humidity and particles number size distribution on aerosol light extinction in the urban area of Guangzhou
}

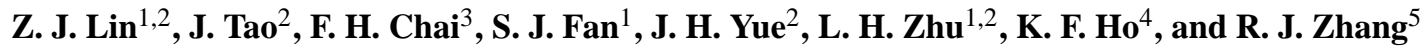 \\ ${ }^{1}$ Department of Atmospheric Science, Sun Yat-Sen University, Guangzhou, China \\ ${ }^{2}$ South China Institute of Environmental Sciences, Guangzhou, China \\ ${ }^{3}$ Chinese Research Academy of Environmental Sciences, Beijing, China \\ ${ }^{4}$ School of Public Health and Primary Care, The Chinese University of Hong Kong, Hongkong, China \\ ${ }^{5}$ RCE-TEA, Institute of Atmospheric Physics, Chinese Academy of Sciences, Beijing, China
}

Correspondence to: S. J. Fan (eesfsj@mail.sysu.edu.cn)

Received: 6 June 2012 - Published in Atmos. Chem. Phys. Discuss.: 22 June 2012

Revised: 4 December 2012 - Accepted: 17 December 2012 - Published: 1 February 2013

\begin{abstract}
In the urban area of Guangzhou, observations on aerosol light extinction effect were conducted at a monitoring site of the South China Institute of Environmental Sciences (SCIES) during April 2009, July 2009, October 2009 and January 2010. The main goal of these observations is to recognise the impact of relative humidity $(\mathrm{RH})$ and particles number distribution on aerosol light extinction. $\mathrm{PM}_{2.5}$ was sampled by Model PQ200 air sampler; ions and OC/EC in $\mathrm{PM}_{2.5}$ were identified by the Dionex ion chromatography and the DRI model 2001 carbon analyser, respectively; particles number size distribution was measured by TSI 3321 APS, while total light scattering coefficient was measured by TSI 3563 Nephelometer. Chemical composition of $\mathrm{PM}_{2.5}$ was reconstructed by the model ISORROPIA II. As a result, possible major components in $\mathrm{PM}_{2.5}$ were $\left(\mathrm{NH}_{4}\right)_{2} \mathrm{SO}_{4}$, $\mathrm{Na}_{2} \mathrm{SO}_{4}, \mathrm{~K}_{2} \mathrm{SO}_{4}, \mathrm{NH}_{4} \mathrm{NO}_{3}, \mathrm{HNO}_{3}$, water, POM and EC. Regarding ambient $\mathrm{RH}$, mass concentration of $\mathrm{PM}_{2.5}$ ranged from 26.1 to $279.1 \mu \mathrm{g} \mathrm{m}^{-3}$ and had an average of $94.8,44.6$, 95.4 and $130.8 \mu \mathrm{g} \mathrm{m}^{-3}$ in April, July, October and January, respectively. With regard to the total mass of $\mathrm{PM}_{2.5}$, inorganic species, water, POM, EC and the Residual accounted for $34-47 \%, 19-31 \%, 14-20 \%, 6-8 \%$ and $8-17 \%$, respectively. Under the assumption of "internal mixture", optical properties of $\mathrm{PM}_{0.5-20}$ were estimated following the Mie Model. Optical refractive index, hygroscopic growth factor and the dry aerosol density required by the Mie Model were determined with an understanding of chemical composition of $\mathrm{PM}_{2.5}$. With these three parameters and the validated particles number size distribution of $\mathrm{PM}_{0.5-20}$, the temporal vari-
\end{abstract}

ation trend of optical property of $\mathrm{PM}_{0.5-20}$ was estimated with good accuracy. The highest average of $b_{\mathrm{ep}, \mathrm{pm} 0.5-20}$ was $300 \mathrm{Mm}^{-1}$ in April while the lowest one was $78.6 \mathrm{Mm}^{-1}$ in July. Regarding size distribution of $b_{\mathrm{ep}, \mathrm{pm} 0.5-20}$, peak value was almost located in the diameter range between 0.5 and $1.0 \mu \mathrm{m}$. Furthermore, hygroscopic growth of optical properties of $\mathrm{PM}_{0.5-20}$ largely depended on RH. As RH increased, $b_{\text {ep,pm0.5-20 }}$ grew and favoured a more rapid growth when aerosol had a high content of inorganic water-soluble salts. Averagely, $f_{\text {bep,pm0.5-20 }}$ enlarged 1.76 times when RH increased from $20 \%$ to $90 \%$. With regard to the temporal vari-

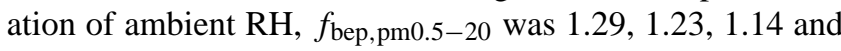
1.26 on average in April, July, October and January, respectively.

\section{Introduction}

Aerosol pollution affects radiation budget of the EarthAtmosphere system by its light extinction. As a result, the global climate changes dramatically (Seinfeld and Pandis, 2006). On the basis of the Mie Model (Bohren and Huffman, 1998), this effect of light extinction can be quantified with the knowledge of single particle light extinction efficiency and particles number size distribution.

Understanding chemical composition is essential to determine the single particle light extinction efficiency. Scientists have developed various kinds of instruments to distinguish the chemical components such as inorganic salts, 
organic carbon (OC), element carbon (EC) and crustal elements. Moreover, water-soluble inorganic salts and watersoluble fraction of organic matters absorb water when relative humidity $(\mathrm{RH})$ increases. Subsequently, numerical models like ISORROPIA II (Fountoukis and Nenes, 2007), EAIM (Wexler and Clegg, 2002) and "Sea Salt" (Eichler et al., 2008) have been developed to recognise the chemical and physical forms of species in aerosol particle at the equilibrium state. However, few details about determining the optical refractive index (ORI) of aerosol particle based on these models were reported.

In Pearl River Delta (PRD) region of China, air visibility degradation in recent years due to an enhancing effect of light extinction made the public and scientists focus attentions on aerosol pollution. And the phenomenon of this pollution was reported in lots of studies (Wang et al., 2003; Bergin et al., 2004; Louie et al., 2005; Wu et al., 2005; Deng et al., 2008a, b; Tie and Cao, 2009). Furthermore, a series of regional integrated field experiments for investigating this pollution were carried out during 2004 and 2008, which mainly concerned:

- chemical transformations among air pollutants and the influence of regional meteorological conditions on pollution episode (Fan et al., 2008; Su et al., 2008; Zhang et al., 2008a, b; Fan et al., 2011);

- aerosol size-resolved chemical composition and the potential pollutant sources (Gnauk et al., 2008; Liu et al., 2008a, b; Jung et al., 2009; Xiao et al., 2011; Yu et al., 2010; Yue et al., 2010);

- mixture state between EC and the other non-lightabsorption species in particles (Cheng et al., 2006, 2008b);

- aerosol optical properties, their hygroscopicity and radiative direct forcing (Andreae et al., 2008; Cheng et al., 2008a, b; Eichler et al., 2008; Liu et al., 2010).

Besides the measurement by optical instruments, the Mie Model served as quite an important tool in these experiments because it provided information on the influence of chemical composition and particles number size distribution on aerosol optical properties.

Guangzhou is one of the mega cities in PRD region, while it is also one of the monitoring sites in the field experiment mentioned above. For the purpose of an updated and complementary study on aerosol light extinction in the urban area of this city, four months' observation on chemical composition and particles number size distribution were carried out at the monitoring site of SCIES (South China Institute of Environmental Sciences) during April 2009, July 2009, October 2009 and January 2010 which represented spring, summer, autumn and winter, respectively. In the light of measurement techniques and numerical models adopted in the previous field experiments, current study tries to reconstruct aerosol chemical composition following the ISORROPIA II model at first, then to estimate the extent of light extinction effect with a practical method that was based on the result derived from APS (Aerodynamic Particle Sizer) and $\mathrm{PM}_{2.5}$ sampling. RH dependence of aerosol optical properties will also be discussed.

\section{Experiment}

\subsection{Monitoring site}

The monitoring site of SCIES is located in the urban area of Guangzhou, whose geographical coordinates are $23^{\circ} 07^{\prime} \mathrm{N}$ and $113^{\circ} 21^{\prime}$ E. For monitoring air quality influenced by pollutants' regional transport and local sources' emission, instruments were all installed on the roof of the building $53 \mathrm{~m}$ above the ground. This site was built with a clear vision of over 300 degrees, around which there is a residential area and a park about $500 \mathrm{~m}$ northeast of it. There is no big air pollution source within a circumference of $3 \mathrm{~km}$ except mobile emissions. A satellite photo depicting the site's location and its surroundings is illustrated in Fig. 1. So far, data on aerosol samples, gaseous pollutants and meteorological parameters have been recorded over a long period of time, some of which were once reported in a previous study (Tao et al., 2009).

\subsection{Sampling and analysis}

\subsubsection{Aerosol sampling}

$\mathrm{PM}_{2.5}$ samples were measured by an air sampler (BGI Corporation, Model PQ200) equipped with a cyclone that separates $\mathrm{PM}_{2.5}$ particles from the aerosol population and with a vacuum pump that draws air at a flow rate of $16.7 \mathrm{~L} \mathrm{~min}^{-1}$. The drawn airstream was connected to a $47 \mathrm{~mm}$ quartz filter (Whatman, QM-A). Before sampling, the quartz filters were baked at $800^{\circ} \mathrm{C}$ for more than $3 \mathrm{~h}$ to remove adsorbed organic vapours, and then equilibrated in desiccators for $24 \mathrm{~h}$. Prior to the measurement in ambient, the flow rate of $\mathrm{PM}_{2.5}$ sampler was calibrated. Blank filters were collected and used to subtract the positive artifact caused by gas absorption. Totally, 123 daily quartz-filter samples with some blank ones were collected for every $23.5 \mathrm{~h}$ (starting at 10:00 LST each day and ending at 09:30 LST the following day) in the four months. The analysis-ready samples were stored in a freezer at about $-20^{\circ} \mathrm{C}$ in case of particle volatilisation.

In OC/EC analysis, a punch of $0.5 \mathrm{~cm}^{2}$ from the collected quartz filter was analysed for eight carbon fractions following the IMPROVE_A thermal/optical reflectance (TOR) protocol by a DRI model 2001 carbon analyser (Atmoslytic Inc., Calabasas, CA) (Cao et al., 2007; Chow et al., 2007). This process produced four $\mathrm{OC}$ fractions $(\mathrm{OC} 1, \mathrm{OC} 2, \mathrm{OC} 3$ and OC4) at $140^{\circ} \mathrm{C}, 280^{\circ} \mathrm{C}, 480^{\circ} \mathrm{C}$ and $580^{\circ} \mathrm{C}$, respectively, in a helium [He] atmosphere; OP (a pyrolysed carbon fraction) was determined when transmitted laser light attained 


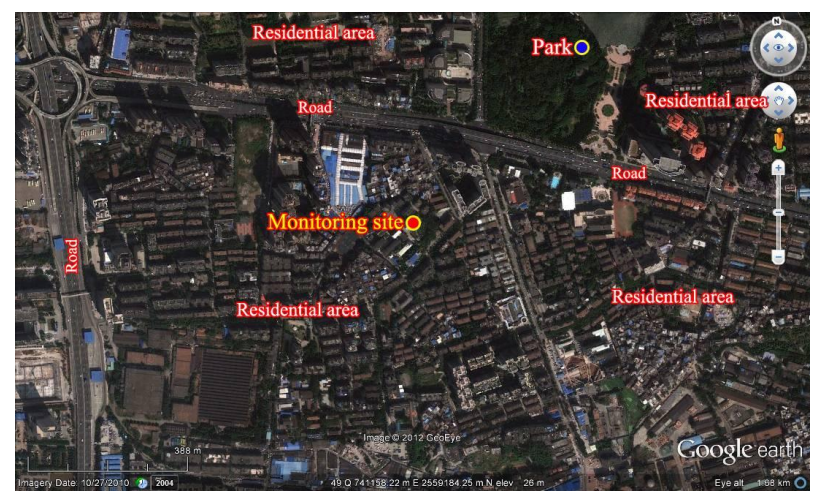

Fig. 1. Satellite photo of the monitoring site and surroundings (from Google Earth).

its original intensity after oxygen $\left[\mathrm{O}_{2}\right]$ added to that analysis atmosphere; and three $\mathrm{EC}$ fractions (EC1, EC2 and EC3) were determined at $580^{\circ} \mathrm{C}, 740^{\circ} \mathrm{C}$ and $840^{\circ} \mathrm{C}$, respectively, in a $(2 \%) \mathrm{O}_{2} /(98 \%)[\mathrm{He}]$ atmosphere. IMPROVE_TOR OC is practically defined as $\mathrm{OC} 1+\mathrm{OC} 2+\mathrm{OC} 3+\mathrm{OC} 4+\mathrm{OP}$, while EC is defined as EC1 + EC2 + EC3 - OP (Chow et al., 2007). Inter-laboratory sample comparisons between applying the IMPROVE_TOR protocol and the TMO (thermal manganese dioxide oxidation) approach have shown the differences being lower than $5 \%$ for TC and $10 \%$ for OC and EC (Chow et al., 2007). Average field blanks were 1.8 and $0.1 \mu \mathrm{g} \mathrm{m}^{-3}$ for OC and $\mathrm{EC}$, respectively.

In analysis of water-soluble ions, one quarter of the collected quartz filter sample was used to determine the ions' mass concentrations. Four anions $\left(\mathrm{SO}_{4}^{2-}, \mathrm{NO}_{3}^{-}, \mathrm{Cl}^{-}\right.$and $\left.\mathrm{F}^{-}\right)$ and five cations $\left(\mathrm{Na}^{+}, \mathrm{NH}_{4}^{+}, \mathrm{K}^{+}, \mathrm{Mg}^{2+}\right.$ and $\left.\mathrm{Ca}^{2+}\right)$ in aqueous extracts from the filter were determined by ion chromatography (Dionex Corp, Sunnyvale, CA, Model Dionex 600). For these extractions, each sample was put into a separate $20 \mathrm{~mL}$ vial containing $10 \mathrm{~mL}$ distilled-deionised water (18 M $\Omega$ resistivity), and shaken first by an ultrasonic instrument for $60 \mathrm{~min}$, then by a mechanical shaker for $1 \mathrm{~h}$ for a complete extraction. The extracts were stored at $4{ }^{\circ} \mathrm{C}$ in a pre-cleaned tube before further analysis. Cation $\left(\mathrm{Na}^{+}\right.$, $\mathrm{NH}_{4}^{+}, \mathrm{K}^{+}, \mathrm{Mg}^{2+}$ and $\mathrm{Ca}^{2+}$ ) concentrations were determined with a CS12A column (Dionex Corp, Sunnyvale, CA.) and $20 \mathrm{mmol} \mathrm{L}{ }^{-1} \mathrm{MSA}$ eluent. Anions $\left(\mathrm{SO}_{4}^{2-}, \mathrm{NO}_{3}^{-}, \mathrm{Cl}^{-}\right.$and $\mathrm{F}^{-}$) were separated by an AS11-HC column (Dionex Corp, Sunnyvale, CA) and $20 \mathrm{mmol} \mathrm{L}^{-1} \mathrm{KOH}$ eluent. The limits of detection were less than $0.05 \mathrm{mg} \mathrm{L}^{-1}$ for both cations and anions. Standard reference materials produced by the National Research Centre for Certified Reference Materials in China were analysed for the purposes of quality assurance. Blank values were subtracted from sample concentrations (Shen et al., 2008).

It is said that there may be artifacts when using quartz filter for $\mathrm{PM}_{2.5}$ sampling. However, the high loading of $\mathrm{PM}_{2.5}$ together with the damp climate in Guangzhou can block the
Teflon filter easily, which affects the flow rate of the sampler and increases the sampling error. For this reason, there were studies (Shen et al., 2009; Wang et al., 2011) on aerosol sampling in China using the quartz filter. Moreover, though the loss of quartz filter debris may lead to the underestimation of aerosol mass, careful operations in the process of sampling and mass weighing minimised this loss as much as possible in the current study.

The field blanks were determined and the average values of 12 blank filters of $\mathrm{Na}^{+}, \mathrm{NH}_{4}^{+}, \mathrm{K}^{+}, \mathrm{Mg}^{2+}, \mathrm{Ca}^{2+}, \mathrm{F}^{-}$, $\mathrm{Cl}^{-}, \mathrm{NO}_{3}^{-}$, and $\mathrm{SO}_{4}^{2-}$ were $0.671 \pm 0.091,0.002 \pm 0.002$, $0.005 \pm 0.006,0.006 \pm 0.007,0.052 \pm 0.064,0.168 \pm 0.036$, $0.425 \pm 0.094,0.077 \pm 0.096$ and $0.362 \pm 0.082 \mathrm{mg} \mathrm{L}^{-1}$, respectively. Although the blank value of $\mathrm{Na}^{+}, \mathrm{F}^{-}, \mathrm{Cl}^{-}$and $\mathrm{Ca}^{2+}$ were slightly higher than other species, blank filter was collected every 10 samples and the blank values were quite stable. All results in the present study were blank subtracted. Moreover, the values of ambient samples were significantly higher than the blank value, which can reduce the errors.

\subsubsection{Measurement of particles number size distribution}

Particles number size distribution of $\mathrm{PM}_{0.5-20}$ was measured by APS (TSI Aerodynamic Sizer, Model 3321) with 52 size bins in the diameter range from 0.5 to $20 \mu \mathrm{m}$ by determining the time-of-flight of an individual particle in an accelerating flow field. To capture dry particles, a drying tube was added in the process of drawing air. Flow rate of $5 \mathrm{~L} \mathrm{~min}^{-1}$ and 5 min data average were set in APS operation.

\subsubsection{RH measurement}

Ambient RH had been recorded every $30 \mathrm{~min}$ by an automatic weather station (VASALA Model QMH102).

\subsubsection{Aerosol optical properties measurement}

Total light scattering coefficient of aerosol was measured by an integrating Nephelometer (TSI Performance Measurement Tools, Model 3563) in wavelengths of $450 \mathrm{~nm}$, $550 \mathrm{~nm}$ and $700 \mathrm{~nm}$, respectively. Nephelometer calibration was performed by carbon dioxide $\left(\mathrm{CO}_{2}\right)$ as high-span gas and filtered air as low-span gas. Nephelometer drew ambient air through a temperature-controlled inlet at a flow rate of $20 \mathrm{~L} \mathrm{~min}^{-1}$. The inner heater controlled the RH of air intake at a level lower than nearly $70 \%$. The output data were set to be $1 \mathrm{~min}$ average, and zero level data was measured continuously for $5 \mathrm{~min}$ after each hourly (60 min) sampling.

The aerosol properties and meteorological parameters measured during the four months' observations are summarised in Table 1.

The result of total light scattering coefficient was corrected for Angular Nonidealities following the method stated in a previous study (Anderson and Ogren, 1998) where a lin-

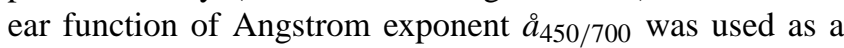


Table 1. Measured aerosol properties and meteorological parameters.

\begin{tabular}{|c|c|c|c|c|c|c|c|}
\hline \multicolumn{2}{|r|}{ Data Set } & \multirow{2}{*}{$\begin{array}{l}\text { Relative } \\
\text { humidity }\end{array}$} & \multirow{2}{*}{$\begin{array}{l}\text { Time } \\
\text { resolution }\end{array}$} & \multicolumn{4}{|c|}{ Available data in days } \\
\hline & & & & Apr-09 & Jul-09 & Oct-09 & Jan-10 \\
\hline 1 & $\mathrm{PM}_{2.5}$ mass concentration & $40 \%$ & $23.5 \mathrm{~h}$ & 30 & 31 & 31 & 31 \\
\hline 2 & Total light scattering coefficient $(450 \mathrm{~nm}, 550 \mathrm{~nm}, 700 \mathrm{~nm})$ & $17-73 \% *$ & $1 \mathrm{~min}$ & 29 & 31 & 31 & 31 \\
\hline 3 & Particles number concentration in the range of $0.5-20 \mu \mathrm{m}$ & dry & $5 \mathrm{~min}$ & 30 & 30 & 29 & 31 \\
\hline 4 & Relative humidity & $29-88 \%$ & $30 \mathrm{~min}$ & 30 & 31 & 31 & 30 \\
\hline
\end{tabular}

* Stands for the RH detected by a built-in RH sensor in Nephelometer.

correction factor. Furthermore, the results of particles number concentration, total light scattering coefficient and $\mathrm{RH}$ were calculated into daily averages to be compatible with daily $\mathrm{PM}_{2.5}$ samples. Blank records in these parameters were estimated by a linear interpolation based on those validated ones.

\section{Methodology}

\subsection{Chemical composition reconstruction}

On the basis of identified cations $\left(\mathrm{Na}^{+}, \mathrm{NH}_{4}^{+}, \mathrm{Ca}^{2+}, \mathrm{K}^{+}\right.$, $\left.\mathrm{Mg}^{2+}\right)$ and anions $\left(\mathrm{SO}_{4}^{2-}, \mathrm{NO}_{3}^{-}, \mathrm{Cl}^{-}\right)$, the model ISORROPIA II was introduced to determine the chemical and physical forms of inorganic species and the content of water uptake. Currently, ISORROPIA II was set to solve a "Forward" problem, the result of which was in "Metastable" state as aerosol particle was assumed to be composed of an aqueous supersaturated solution. Accordingly, several aqueous species $\left(\mathrm{Na}^{+}, \mathrm{HSO}_{4}^{-}, \mathrm{SO}_{4}^{2-}\right.$, etc.) were determined, but to recognise their compound forms is still difficult.

The present study intends to associate these aqueous species into possible compounds according to the five aerosol composition regimes defined in ISORROPIA II. These regimes are "Sulfate Rich (free acid)"; "Sulfate Rich"; "Sulfate Poor, Crustal \& Sodium Poor"; "Sulfate Poor, Crustal \& Sodium Rich, Crustal Poor" and "Sulfate Poor, Crustal \& Sodium Rich, Crustal Rich". Making use of the cations and anions identified in every $\mathrm{PM}_{2.5}$ sample, characteristic parameters $R_{1}$ (Ratio of sum of $\mathrm{Na}^{+}, \mathrm{NH}_{4}^{+}, \mathrm{Ca}^{2+}, \mathrm{K}^{+}, \mathrm{Mg}^{2+}$ to $\mathrm{SO}_{4}^{2-}$ ), $R_{2}$ (Ratio of sum of $\mathrm{Na}^{+}, \mathrm{Ca}^{2+}, \mathrm{K}^{+}, \mathrm{Mg}^{2+}$ to $\mathrm{SO}_{4}^{2-}$ ) and $R_{3}$ (Ratio of sum of $\mathrm{Ca}^{2+}, \mathrm{K}^{+}, \mathrm{Mg}^{2+}$ to $\mathrm{SO}_{4}^{2-}$ ) defined by ISORROPIA II were calculated. With regard to their values, chemical composition of each $\mathrm{PM}_{2.5}$ sample was related to one of the five regimes. Furthermore, one is able to associate those aqueous species into compounds following several principles adopted by the model including:

- there is an electric charge balance in "Metastable" state;

- $\mathrm{Na}^{+}$and $\mathrm{K}^{+}$preferentially associate with $\mathrm{SO}_{4}^{2-}$ before combining with $\mathrm{NO}_{3}^{-}$and $\mathrm{Cl}^{-}$because $\mathrm{SO}_{4}^{2-}$ is less volatile than $\mathrm{NO}_{3}^{-}$and $\mathrm{Cl}^{-}$;
- $\mathrm{SO}_{4}^{2-}$ associates with $\mathrm{Na}^{+}$. If any remain, then it associates with $\mathrm{NH}_{4}^{+}$. The same assumption applies for $\mathrm{HSO}_{4}^{-}$;

- gas species $\mathrm{NH}_{3}, \mathrm{HCl}$ and $\mathrm{HNO}_{3}$ dissolve through the equilibria of the supersaturated aerosol system.

Consequently, possible inorganic species were determined in the form of $\mathrm{NH}_{4} \mathrm{HSO}_{4},\left(\mathrm{NH}_{4}\right)_{2} \mathrm{SO}_{4}, \mathrm{NaHSO}_{4}, \mathrm{Na}_{2} \mathrm{SO}_{4}$, $\mathrm{NH}_{4} \mathrm{NO}_{3}, \mathrm{NaNO}_{3}, \mathrm{NH}_{4} \mathrm{Cl}, \mathrm{NaCl}, \mathrm{K}_{2} \mathrm{SO}_{4}, \mathrm{MgSO}_{4}, \mathrm{CaSO}_{4}$, $\mathrm{KHSO}_{4}, \mathrm{H}_{2} \mathrm{SO}_{4}, \mathrm{NH}_{3}, \mathrm{HCl}$ and $\mathrm{HNO}_{3}$. It should be noted that the volatilisation effect of $\mathrm{NH}_{4} \mathrm{NO}_{3}$ and other semivolatile species was not investigated in the current study.

As the hygroscopicity of water-soluble inorganic salts is considered in ISORROPIA II, the content of water uptake in each $\mathrm{PM}_{2.5}$ sample was also determined.

Particulate organic matter (POM) is an important chemical component, which was estimated by the content of OC being multiplied by a factor of 1.6 (Cao et al., 2007). On the other hand, the hygroscopicity of POM is not considered currently because:

- as a whole, the hygroscopic growth of Secondary Organic Aerosol (SOA) was found to be around 1.2 at $90 \%$ RH (Gysel et al., 2007; Stock et al., 2011);

- the hygroscopicity of some extracts from Water Soluble Organic Carbon (WSOC) has been recognised (Gysel et al., 2004). However, there is no WSOC speciation in the present study;

- water uptake by the aged organic aerosol accounted for only a few percent of total water uptake (Bougiatioti et al., 2009; Engelhart et al., 2011);

- unlike the water-soluble inorganic salts, a more accurate $\mathrm{RH}$ dependence curve of POM has not been well established;

- organic species have not been included in the ISORROPIA II model.

Since inorganic species, water, POM and EC were recognised, remaining unidentified species were categorised to the "Residual". EC and the Residual were assumed to have no 
Table 2. Summary of the parameters for calculating the EORI and EGF.

\begin{tabular}{lccclccc}
\hline Specie & $\rho_{i}\left(\mathrm{~g} \mathrm{~cm}^{-3}\right)$ & $n_{i}$ & $k_{i}$ & Specie & $\rho_{i}\left(\mathrm{~g} \mathrm{~cm}^{-3}\right)$ & $n_{i}$ & $k_{i}$ \\
\hline $\mathrm{NH}_{4} \mathrm{HSO}_{4}$ & 1.780 & 1.473 & 0.000 & $\mathrm{Ca}\left(\mathrm{NO}_{3}\right)_{2}$ & 2.504 & 1.530 & 0.000 \\
$\left(\mathrm{NH}_{4}\right)_{2} \mathrm{SO}_{4}$ & 1.760 & 1.530 & 0.000 & $\mathrm{CaCl}_{2}$ & 2.150 & 1.520 & 0.000 \\
$\mathrm{NaHSO}_{4}$ & 2.476 & 1.460 & 0.000 & $\mathrm{Mg}\left(\mathrm{NO}_{3}\right)_{2}$ & 2.020 & 1.510 & 0.000 \\
$\mathrm{Na}_{2} \mathrm{SO}_{4}$ & 2.680 & 1.480 & 0.000 & $\mathrm{MgCl}_{2}$ & 2.325 & 1.540 & 0.000 \\
$\mathrm{NH}_{4} \mathrm{NO}_{3}$ & 1.725 & 1.554 & 0.000 & $\mathrm{KNO}_{3}$ & 2.110 & 1.504 & 0.000 \\
$\mathrm{NaNO}_{3}$ & 2.261 & 1.587 & 0.000 & $\mathrm{KCl}_{4}$ & 1.980 & 1.490 & 0.000 \\
$\mathrm{NH}_{4} \mathrm{Cl}$ & 1.527 & 1.639 & 0.000 & $\mathrm{NH}_{3}$ & 0.597 & 1.000 & 0.000 \\
$\mathrm{NaCl}_{\mathrm{K}} \mathrm{SO}_{4}$ & 2.160 & 1.544 & 0.000 & $\mathrm{HCl}$ & 1.200 & 1.250 & 0.000 \\
$\mathrm{MgSO}_{4}$ & 2.660 & 1.490 & 0.000 & $\mathrm{HNO}$ & 1.500 & 1.400 & 0.000 \\
$\mathrm{CaSO}_{4}$ & 2.660 & 1.560 & 0.000 & Water & 1.000 & 1.333 & 0.000 \\
$\mathrm{H}_{2} \mathrm{SO}_{4}$ & 2.610 & 1.570 & 0.000 & $\mathrm{POM}$ & 1.400 & 1.550 & 0.001 \\
$\mathrm{KHSO}_{4}$ & 1.840 & 1.430 & 0.000 & EC & 1.500 & 1.800 & 0.540 \\
& 2.245 & 1.480 & 0.000 & Residual & 2.000 & 1.580 & 0.005 \\
\hline
\end{tabular}

hygroscopic growth. In this regard, the content of the Residual was the difference between $\mathrm{PM}_{2.5}$ and the sum of the identified species at $40 \% \mathrm{RH}$. Furthermore, mass concentration of $\mathrm{PM}_{2.5}$ at any other $\mathrm{RH}$ condition can be calculated based on this determined content of the Residual.

\subsection{Aerosol optical property estimation}

In consideration of the APS measurement and $\mathrm{PM}_{2.5}$ sampling in the present study, an assumption of "internal mixture" was introduced into the Mie Model, which considers every chemical component in a particle as homogeneously mixing with each other (Jacobson, 2001; Bond and Bergstrom, 2006; Cheng et al., 2008c).

The EORI represents the "average" ORI of an "internal mixture" particle, which can be calculated with the ORI of each component following mixing rule of Volume-Average (Lesins et al., 2002). The formulas for the EORI are written as Eqs. (1) and (2).

$$
\begin{aligned}
& n_{\mathrm{eff}}=\left(\sum_{i} n_{i} \cdot m_{i} / \rho_{i}\right) /\left(\sum_{i} m_{i} / \rho_{i}\right) \\
& k_{\mathrm{eff}}=\left(\sum_{i} k_{i} \cdot m_{i} / \rho_{i}\right) /\left(\sum_{i} m_{i} / \rho_{i}\right)
\end{aligned}
$$

In Eqs. (1) and (2), $m_{i}$ stands for mass concentration of the $i$-th component in particles, while $\rho_{i}$ is the density. Respectively, $n_{i}$ is the real part of ORI of the $i$-th component, $k_{i}$ is the imaginary part. Regarding the EORI, $n_{\text {eff }}$ is the real part, and $k_{\text {eff }}$ is the imaginary part.

Furthermore, the EGF is the "average" hygroscopic growth factor, which can be calculated with Eq. (3) (Eichler et al., 2008).

$$
f_{\mathrm{eff}}=\left(\sum_{i} \varepsilon_{i} \cdot f_{\mathrm{g}, i}^{3}\right)^{1 / 3}=\left(\frac{V_{\mathrm{water}}+V_{\mathrm{dry}}}{V_{\text {dry }}}\right)^{1 / 3}=\left(\frac{m_{\mathrm{wet}}}{m_{\mathrm{dry}}} \cdot \frac{\rho_{\mathrm{dry}}}{\rho_{\mathrm{wet}}}\right)^{1 / 3}
$$

$\rho=\left(\sum_{i} m_{i}\right) /\left(\sum_{i} m_{i} / \rho_{i}\right)$

In Eq. (3), $f_{\text {eff }}$ is the EGF. $\varepsilon_{i}$ is the volume fraction of the $i$-th component in aerosol, while $f_{\mathrm{g}, i}$ is the hygroscopic growth factor. $V_{\text {water }}$ and $V_{\text {dry }}$ is the volume of water uptake and dry particle, respectively. The dry aerosol density, $\rho_{\text {dry }}$, in Eq. (3) can be calculated with Eq. (4) where $\rho_{i}$ is the density of the $i$-th chemical component (excluding water) and $m_{i}$ is mass concentration.

Parameters for calculating the EORI and the EGF are summarised in Table 2, which were learned from previous studies (Tang, 1996; Chazette and Louisse, 2001; Sloane, 1986; Haynes, 2011; Seinfeld and Pandis, 2006; Eichler et al., 2008). $n_{i}$ and $k_{i}$ in the table are referenced to light wavelength of $550 \mathrm{~nm}$.

According to the Mie Model, $b_{\mathrm{sp}}$ (light scattering coefficient) and $b_{\text {ep }}$ (light extinction coefficient) can be quantified with Eqs. (5) and (6) (Bohren and Huffman, 1998; Seinfeld and Pandis, 2006), respectively. $b_{\text {ap }}$ (light absorption coefficient) is the difference between $b_{\text {ep }}$ and $b_{\text {sp }}$. Optical properties including $b_{\mathrm{ep}}, b_{\mathrm{sp}}$ and $b_{\mathrm{ap}}$ to be discussed later are all referenced to light wavelength of $550 \mathrm{~nm}$.

$b_{\mathrm{sp}}=\sum_{j} b_{\mathrm{sp}, j}=\sum_{j} \frac{\pi D_{j}^{2}}{4} \cdot Q_{\mathrm{sp}, j}\left(D_{j}, \lambda, \mathrm{EORI}_{j}\right) \cdot N_{j}$

$b_{\mathrm{ep}}=\sum_{j} b_{\mathrm{ep}, j}=\sum_{j} \frac{\pi D_{j}^{2}}{4} \cdot Q_{\mathrm{ep}, j}\left(D_{j}, \lambda, \mathrm{EORI}_{j}\right) \cdot N_{j}$

In Eqs. (5) and (6), $D_{j}$ stands for the midpoint Stokes Diameter in the $j$-th particle size range, while $N_{j}$ is the number concentration of particles with diameter $D_{j} . Q_{\mathrm{sp}, j}$ represents light scattering efficiency of a single particle with diameter $D_{j}$, while $Q_{\mathrm{ep}, j}$ represents light absorption efficiency. Theoretically, $Q_{\mathrm{sp}, j}$ and $Q_{\mathrm{ep}, j}$ are both the function of $D_{j}$ and the EORI $_{j}$ (the EORI of the particle with diameter $D_{j}$ ) at a given 

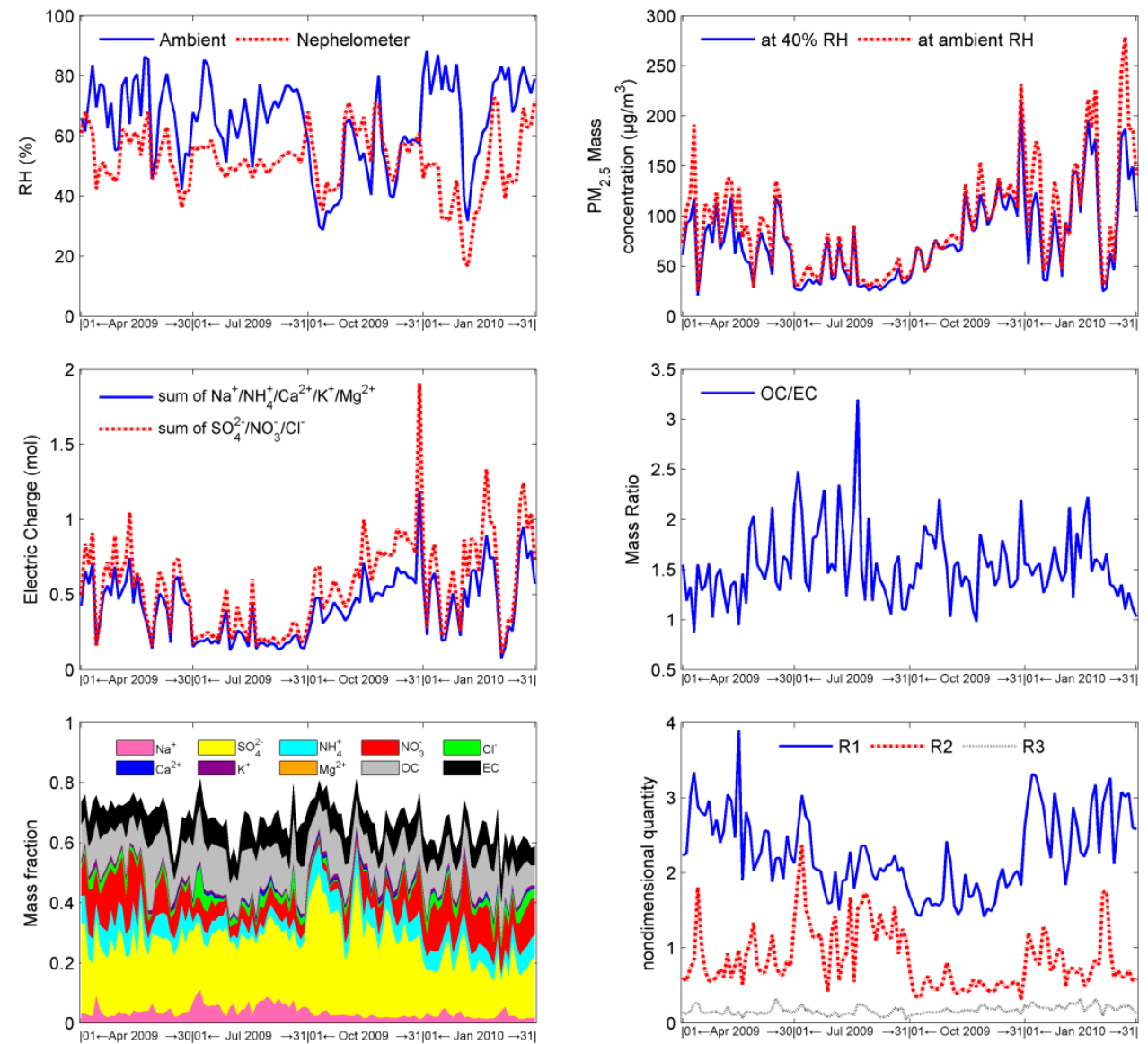

Fig. 2. Temporal variations of RH, $\mathrm{PM}_{2.5}$ mass, molarity of electric charge, ratio of OC to EC, components' mass fraction and characteristic values $\left(R_{1}, R_{2}, R_{3}\right)$.

light wavelength $\lambda$ (say $550 \mathrm{~nm}$ ), for which the complicated calculations were referenced to a previous publication (Seinfeld and Pandis, 2006). Regarding the limitation of measurement techniques, the EORI ${ }_{j}$ was assumed to be equal to the EORI $_{\mathrm{pm} 2.5}$ which was determined based on chemical composition of $\mathrm{PM}_{2.5}$.

The $D_{j}$ required by the Mie Model was converted from $D_{\mathrm{a}, j}$ of APS size bin with Eq. (7), while the corresponding $\mathrm{N}_{j}$ was derived from APS. Moreover, $f_{\mathrm{eff}, j}$ in Eq. (7) represented the hygroscopicity of $D_{j}$ under an assumption that no change in particles number through the process of hygroscopic growth (Eichler et al., 2008). Sharing the similarity of $\mathrm{EORI}_{j}, f_{\mathrm{eff}, j}$ was assumed to be equal to the $\mathrm{f}_{\mathrm{eff}, \mathrm{pm} 2.5}$.

$D_{j}=\frac{D_{\mathrm{a}, j}}{\sqrt{\rho_{\mathrm{dry}}}} \cdot f_{\mathrm{eff}, j}$.

\section{Result and discussion}

\subsection{Chemical composition of $\mathrm{PM}_{2.5}$}

As illustrated in Fig. 2, mass concentration of $\mathrm{PM}_{2.5}$ at $40 \% \mathrm{RH}$ ranged from 21.0 to $213.6 \mu \mathrm{g} \mathrm{m}^{-3}$ during the four months, and the average of 76.0, 38.6, 89.3 and $103.3 \mu \mathrm{g} \mathrm{m}^{-3}$ were recorded in April, July, October and January, respectively. Figure 2 also shows a coherent temporal variation between the sum of the anions and that of the cations, with the former being sufficient to neutralise the latter. Regarding the content of components in $\mathrm{PM}_{2.5}$, inorganic ions accounted for $33-57 \%$ of total mass; OC was $12-14 \%$, while EC was about $8 \%$. The mass ratio of $\mathrm{OC}$ to $\mathrm{EC}$ ranged from 0.9 to 3.2 and had an average of 1.5 during the four months.

Characteristic values $R_{1}, R_{2}$ and $R_{3}$ were calculated and their temporal variations are illustrated in Fig. 2 as well. $\mathrm{PM}_{2.5}$ samples were then related to the five aerosol chemical composition regimes. It should be noted that the electric charge balance in the aerosol system is examined by ISORROPIA II itself, and no unbalance was detected in the current study. 

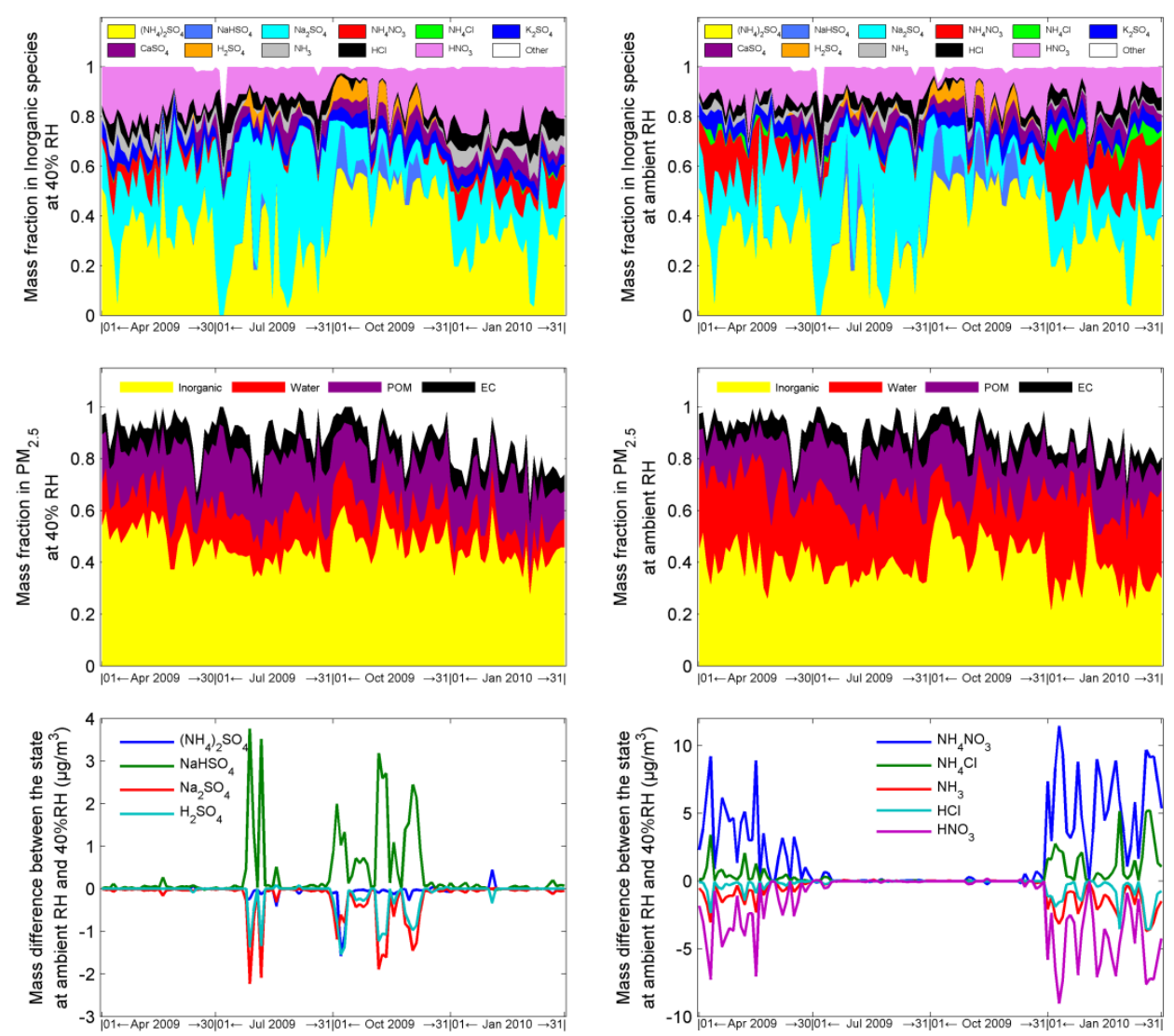

Fig. 3. Temporal variations of chemical composition of $\mathrm{PM}_{2.5}$ at $40 \% \mathrm{RH}$ and ambient $\mathrm{RH}$.

Table 3 notes that the prevailing regime was "Sulfate Poor, Crustal \& Sodium Poor" in April and January, while "Sulfate rich" in October. These two regimes accounted for about $32 \%$ and $65 \%$ of total samples in July, respectively. During October, a drier climate with strong solar radiation in South China probably accelerated the oxidation process of $\mathrm{SO}_{2}$ to become $\mathrm{SO}_{4}^{2-}$, hence the content of sulfate in ambient atmosphere was getting richer.

According to the methodology mentioned earlier, chemical composition of $\mathrm{PM}_{2.5}$ was reconstructed, whose temporal variations are illustrated in Fig. 3. It should be noted that an empirical OC/POM conversion probably leads to an overestimation of POM besides the errors in measurements and water content calculation. As a result, mass of the Residual in 10 of the 123 samples were calculated to small negatives. To avoid this matter affecting further calculation in the Mie Model, these negative values were assigned to zero. As illustrated in Fig. 3, of the total mass, inorganic species, water, POM, EC and the Residual accounted for $42-51 \%, 10$ $15 \%, 17-23 \%, 8-9 \%$ and $10-22 \%$, respectively. Moreover, $\left(\mathrm{NH}_{4}\right)_{2} \mathrm{SO}_{4}, \mathrm{Na}_{2} \mathrm{SO}_{4}, \mathrm{~K}_{2} \mathrm{SO}_{4}$ and $\mathrm{HNO}_{3}$ are the major inorganic species during the four months. In October, the content of $\mathrm{NH}_{4} \mathrm{HSO}_{4}$ and $\mathrm{H}_{2} \mathrm{SO}_{4}$ rose for a sulfate rich atmosphere.
$\mathrm{NH}_{4} \mathrm{NO}_{3}$ usually appeared in April and January when there was not enough $\mathrm{HSO}_{4}^{-}$or $\mathrm{SO}_{4}^{2-}$ to neutralise the $\mathrm{NH}_{4}^{+}$.

As mentioned above, $\mathrm{PM}_{2.5}$ mass at ambient $\mathrm{RH}$ was determined according to its mass at $40 \% \mathrm{RH}$. With regard to the content at $40 \% \mathrm{RH}$, water uptake varied significantly with ambient RH. Compound forms of inorganic species changed as well. As illustrated in Fig. 3, $\mathrm{NaHSO}_{4}, \mathrm{Na}_{2} \mathrm{SO}_{4}$ and $\mathrm{H}_{2} \mathrm{SO}_{4}$ often had significant variations during July and October when sulfate was rich. In April and January, more $\mathrm{NH}_{4}^{+}, \mathrm{Cl}^{-}$and $\mathrm{NO}_{3}^{-}$dissociated from dissolved $\mathrm{NH}_{3}, \mathrm{HCl}$ and $\mathrm{HNO}_{3}$, hence, $\mathrm{NH}_{4} \mathrm{NO}_{3}$ and $\mathrm{NH}_{4} \mathrm{Cl}$ increased their amounts. At ambient RH condition, mass concentration of $\mathrm{PM}_{2.5}$ ranged from 26.1 to $279.1 \mu \mathrm{g} \mathrm{m}^{-3}$ and had an average of 94.8, 44.6, 95.4 and $130.8 \mu \mathrm{g} \mathrm{m}^{-3}$ in April, July, October and January, respectively. With regard to the composition, inorganic species, water, POM, EC and the Residual accounted for $34-47 \%, 19-31 \%, 14-20 \%, 6-8 \%$ and $8-17 \%$ of total mass, respectively.

\subsection{Optical properties of $\mathrm{PM}_{0.5-20}$}

With the understanding of the aerosol chemical composition reconstructed above, the EORI, EGF and $\rho_{\text {dry }}$ required by the Mie Model were determined. Owing to these 
Table 3. Quantities of $\mathrm{PM}_{2.5}$ samples which were categorised to the five chemical composition regimes.

\begin{tabular}{|c|c|c|c|c|c|}
\hline Condition & Regime & Apr-09 & Jul-09 & Oct-09 & Jan-10 \\
\hline$R_{1}<1$ & Sulfate Rich (free acid) & 0 & 0 & 0 & 0 \\
\hline $1 \leq R_{1}<2$ & Sulfate Rich & 3 & 10 & 27 & 1 \\
\hline$R_{1} \geq 2, R_{2}<2$ & Sulfate Poor, Crustal \& Sodium Poor & 27 & 20 & 4 & 30 \\
\hline$R_{1} \geq 2, R_{2} \geq 2, R_{3} \leq 2$ & Sulfate Poor, Crustal \& Sodium Rich, Crustal Poor & 0 & 1 & 0 & 0 \\
\hline$R_{1} \geq 2, R_{2} \geq 2, R_{3}>2$ & Sulfate Poor, Crustal \& Sodium Rich, Crustal Rich & 0 & 0 & 0 & 0 \\
\hline
\end{tabular}
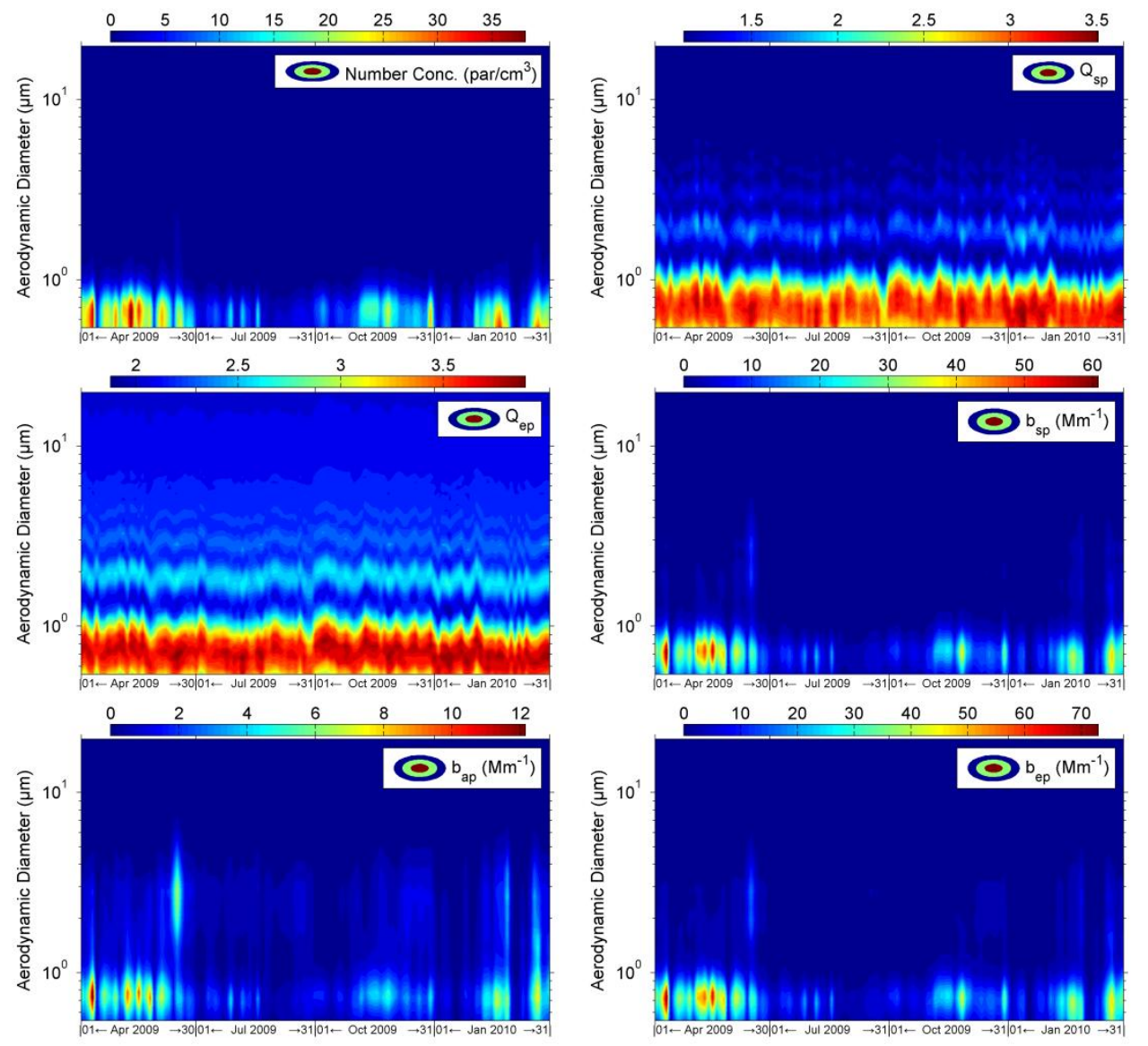

Fig. 4. Temporal variations of particles number and optical properties.

three key parameters and particles number size distribution of $\mathrm{PM}_{0.5-20}$ from APS, $b_{\mathrm{ep}}, b_{\mathrm{sp}}$ and $b_{\text {ap }}$ of $\mathrm{PM}_{0.5-20}$ were calculated following the methodology mentioned earlier. At ambient RH condition, the EORI $\mathrm{pm} 2.5_{\text {had an }}$ average of $1.462-0.037 i$, while $\mathrm{EGF}_{\mathrm{pm} 2.5}$ and $\rho_{\text {dry }}$ was 1.487 and $1.848 \mathrm{~g} \mathrm{~cm}^{-3}$, respectively. Subsequently, size distributions of optical properties of $\mathrm{PM}_{0.5-20}$ were plotted in Fig. 4 where peak values of particles number and optical properties were almost located in the diameter range between 0.5 and $1.0 \mu \mathrm{m}$. Since the volatilisation loss of semi-volatile species was not investigated in present study, the calculated $b_{\mathrm{ep}}$ of $\mathrm{PM}_{0.5-20}$ was probably underestimated when the volatilisation effect was important. Moreover, as organic species have not been considered by the ISORROPIA II, the content of water uptake was slightly underestimated and, therefore, $b_{\mathrm{ep}}$ of $\mathrm{PM}_{0.5-20}$ was probably underestimated.

\subsubsection{Impact of particles number size distribution}

In Fig. 5, temporal variation comparison between $b_{\mathrm{sp}, \mathrm{pm} 0.5-20}$ and $b_{\mathrm{sp}, \mathrm{total}}\left(b_{\mathrm{sp}, \text { total }}\right.$ was measured by Nephelometer) was made in consideration of the former one being subset of the latter. It should be noted that the EORI $\mathrm{pm}_{\mathrm{p} .5}$, $\mathrm{EGF}_{\mathrm{pm} 2.5}$ and $\rho_{\text {dry }}$ for $b_{\mathrm{sp}, \mathrm{pm} 0.5-20}$ in this comparison were calculated at the RH condition inside Nephelometer and had the average of $1.473-0.042 i, 1.406$ and $1.806 \mathrm{~g} \mathrm{~cm}^{-3}$, 

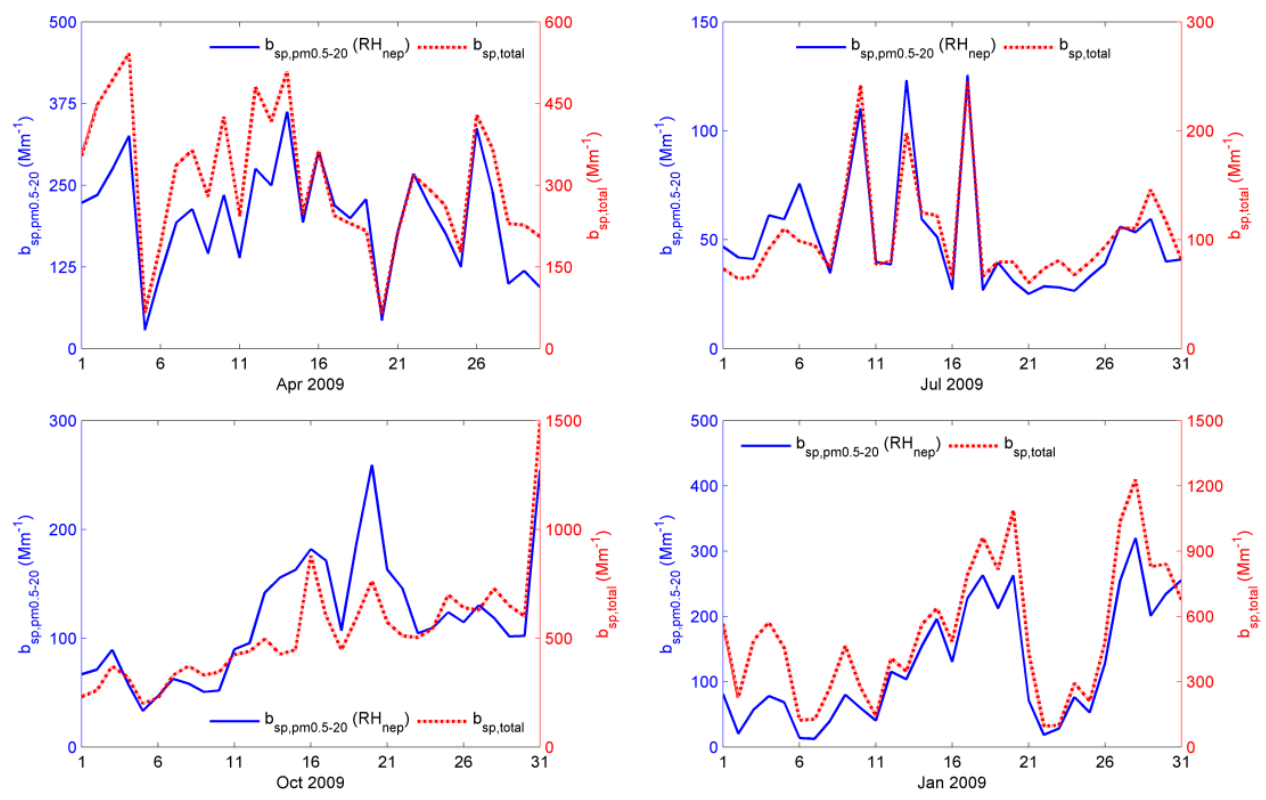

Fig. 5. Comparison between variations of estimation and measurement.

respectively. Figure 5 indicates a coherent temporal variation trend between the two data sets in April, July and January as correlation coefficient was $0.88,0.92$ and 0.94 , respectively. A weaker correlation existed in October with a coefficient of 0.79 . One will speculate that the practical method of calculating $b_{\mathrm{sp}, \mathrm{pm} 0.5-20}$ in this paper can conditionally predict the variation trend of $b_{\mathrm{sp} \text {,total }}$.

In Fig. $6, N_{j}$ of $\mathrm{PM}_{0.5-20}$ showed its strong linear correlations with $b_{\mathrm{sp}, j}$ and $b_{\mathrm{ep}, j}$ of $\mathrm{PM}_{0.5-20}$ at ambient $\mathrm{RH}$ condition. On the contrary, $Q_{\mathrm{sp}, j}$ and $Q_{\mathrm{ep}, j}$ had poor linear correlation with $b_{\mathrm{sp}, j}$ and $b_{\mathrm{ep}, j}$, respectively, which were determined based on the assumptions of EORI ${ }_{j}$ being equaled to the $\mathrm{EORI}_{\mathrm{pm} 2.5}$ and the $f_{\mathrm{eff}, j}$ being equaled to the $f_{\mathrm{eff}, \mathrm{pm} 2.5}$. Furthermore, Fig. 6 illustrates that $N_{\text {pm } 0.5-20}$ had strong linear correlation with $b_{\mathrm{sp}, \mathrm{pm} 0.5-20}$ and $b_{\mathrm{ep}, \mathrm{pm} 0.5-20}$ as correlation coefficient was 0.92 and 0.90 , respectively. In this regard, it can be inferred that those assumptions influenced $b_{\mathrm{sp}, \mathrm{pm} 0.5-20}$ and $b_{\mathrm{ep}, \mathrm{pm} 0.5-20}$ much less significantly than $N_{\mathrm{pm} 0.5-20} \mathrm{did}$, hence the practical method introduced in current study is capable of estimating variation trend of optical property of $\mathrm{PM}_{0.5-20}$ with good accuracy, as long as the data of particles number size distribution is available and validated. Accordingly, a possible reason for the weaker correlation between $b_{\mathrm{sp}, \mathrm{pm} 0.5-20}$ and $b_{\mathrm{sp} \text {,total }}$ in October is that there were many even smaller particles in ambient atmosphere and APS could not distinguish them enough to produce a better particles number size distribution for the estimation. This speculation will be further investigated if a combination of SMPS-APS is introduced in future study.

\subsubsection{Impact of relative humidity}

In order to investigate the hygroscopicity of the optical properties of $\mathrm{PM}_{0.5-20}, f_{\mathrm{g}}=\mathrm{g}(\mathrm{RH}) / \mathrm{g}\left(\mathrm{RH}_{0}\right)$ is used to represent the hygroscopic growth factor, where $\mathrm{g}(\mathrm{RH})$ stands for an optical property at a specific RH condition (denoted in fraction) and $\mathrm{RH}_{0}$ is valued to 0.2 representing the dry state. In the light of a previous paper (Cheng et al., 2008b), a function as Eq. (8) best fitted the RH dependence curve of $f_{\mathrm{g}}$.

$f_{\mathrm{g}}(\mathrm{RH})=\left(\frac{1-\mathrm{RH}}{1-\mathrm{RH}_{0}}\right)^{-a \cdot \mathrm{RH}}$

$R^{2}$ of the curve fittings of all samples were 0.99 on average. Temporal variations of coefficient " $a$ " are plotted in Fig. 7, and judged by which, $b_{\mathrm{sp}, \mathrm{pm} 0.5-20}$ grew more rapidly than

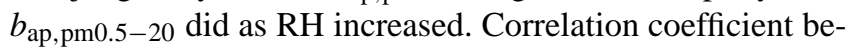
tween " $a$ " of $b_{\mathrm{ep}, \mathrm{pm} 0.5-20}$ and $\gamma_{\text {ion }}$ (mass fraction of ions in $\mathrm{PM}_{2.5}$ ) being 0.86 indicates that different content of ions accounted for the variation of coefficient " $a$ ". Along with an increasing $\mathrm{RH}, b_{\mathrm{ep}, \mathrm{pm} 0.5-20}$ grew and favoured a more rapid growth when aerosol had a high content of inorganic watersoluble salts.

Regarding the average of all samples, $\mathrm{RH}$ dependence curves of $f_{\text {bep,pm0.5-20 }}, f_{\text {bsp,pm0.5-20 }}$ and $f_{\text {bap,pm0.5-20 }}$ are also illustrated in Fig. 7 where circles stand for mean values and bars outline one time standard deviation. When RH increased from $20 \%$ to $90 \%, f_{\text {bep,pm0.5-20 }}, f_{\text {bsp,pm0.5-20 }}$

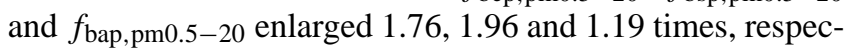
tively. 

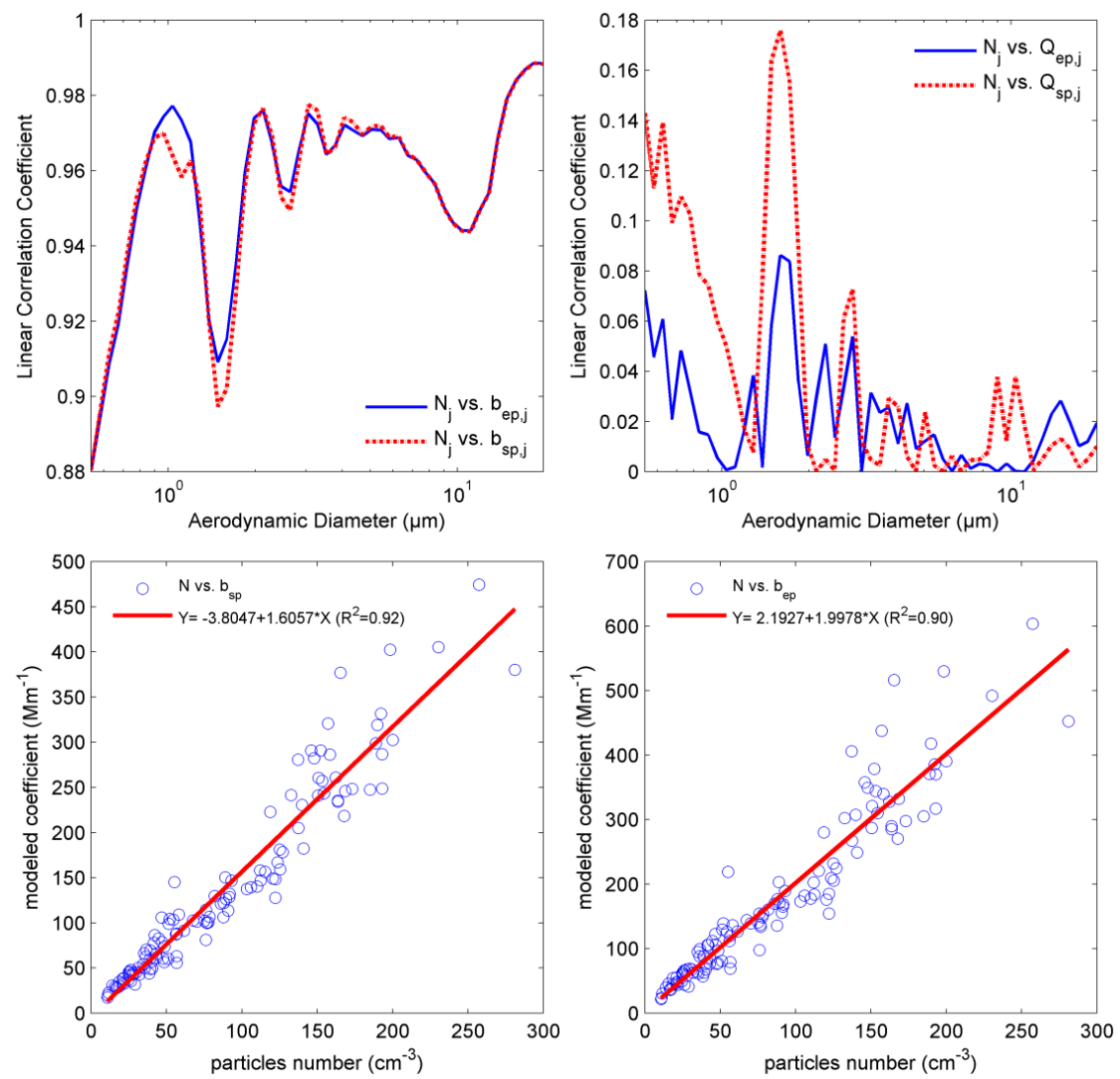

Fig. 6. Linear regressions between particles number and optical properties of $\mathrm{PM}_{0.5-20}$.

Table 4. Potential uncertainties of the model estimation.

\begin{tabular}{|c|c|}
\hline Property & Uncertainty \\
\hline RH recorded by auto weather station ${ }^{\mathrm{a}}$ & $3.87 \%$ \\
\hline$N_{j}$ measured by APS ${ }^{\mathrm{b}}$ & $3.30 \%$ \\
\hline$D_{\mathrm{a}, j}$ from APS ${ }^{\mathrm{b}}$ & $3.00 \%$ \\
\hline ion \& OC/EC analysis ${ }^{\mathrm{c}}$ & $2.49 \%$ \\
\hline $\mathrm{PM}_{2.5}$ sample weighing ${ }^{\mathrm{c}}$ & $1.08 \%$ \\
\hline Real part of the ORI of the $\mathrm{EC}^{\mathrm{b}}$ & $3.00 \%$ \\
\hline Imaginary part of the ORI of the $\mathrm{EC}^{\mathrm{b}}$ & $5.00 \%$ \\
\hline Total & $8.73 \%$ \\
\hline
\end{tabular}

\subsubsection{Uncertainties in model estimation}

Uncertainties of the model estimation discussed above are listed in Table 4, the potential sources of which includes instrumental measurement (analysis) and parameters chosen for the model. The total uncertainty was determined by Eq. (9) which was recommended by IPCC (Intergovernmental Panel on Climate Change). In Eq. (9) below, $U_{\text {total }}$ is the total uncertainty while $U_{i}$ is the $i$-th subset of uncertainties.

$$
U_{\text {total }}=\left(\sum_{i} U_{i}^{2}\right)^{1 / 2}
$$

\section{Summary and conclusion}

In the urban area of Guangzhou, mass concentration of $\mathrm{PM}_{2.5}$ was at its lowest level being $44.6 \mu \mathrm{g} \mathrm{m}^{-3}$ in July 2009 , higher in April 2009 and October 2009, and reached the highest level being $130.8 \mu \mathrm{g} \mathrm{m}^{-3}$ in January 2010. The content of $\mathrm{SO}_{4}^{2-}$ rose in October while was low in January. The content of water uptake dropped in October for a drier climate. Moreover, $\mathrm{NO}_{3}^{-}$increased its content in April and January, while POM and EC had high content in July and October.

On the basis of ions identification from $\mathrm{PM}_{2.5}$ samples, the ISORROPIA II model helped to reconstruct aerosol chemical composition. The major species that constituted $\mathrm{PM}_{2.5}$ particles included $\left(\mathrm{NH}_{4}\right)_{2} \mathrm{SO}_{4}, \mathrm{Na}_{2} \mathrm{SO}_{4}, \mathrm{~K}_{2} \mathrm{SO}_{4}, \mathrm{NH}_{4} \mathrm{NO}_{3}$, $\mathrm{HNO}_{3}$, water, $\mathrm{POM}$ and $\mathrm{EC}$, and the monthly average contents of the major species are listed in Table 5. Regarding ambient RH, inorganic species, water, POM, EC and the Residual accounted for $34-47 \%, 19-31 \%, 14-20 \%, 6-8 \%$ and $8-17 \%$ of total mass, respectively. 

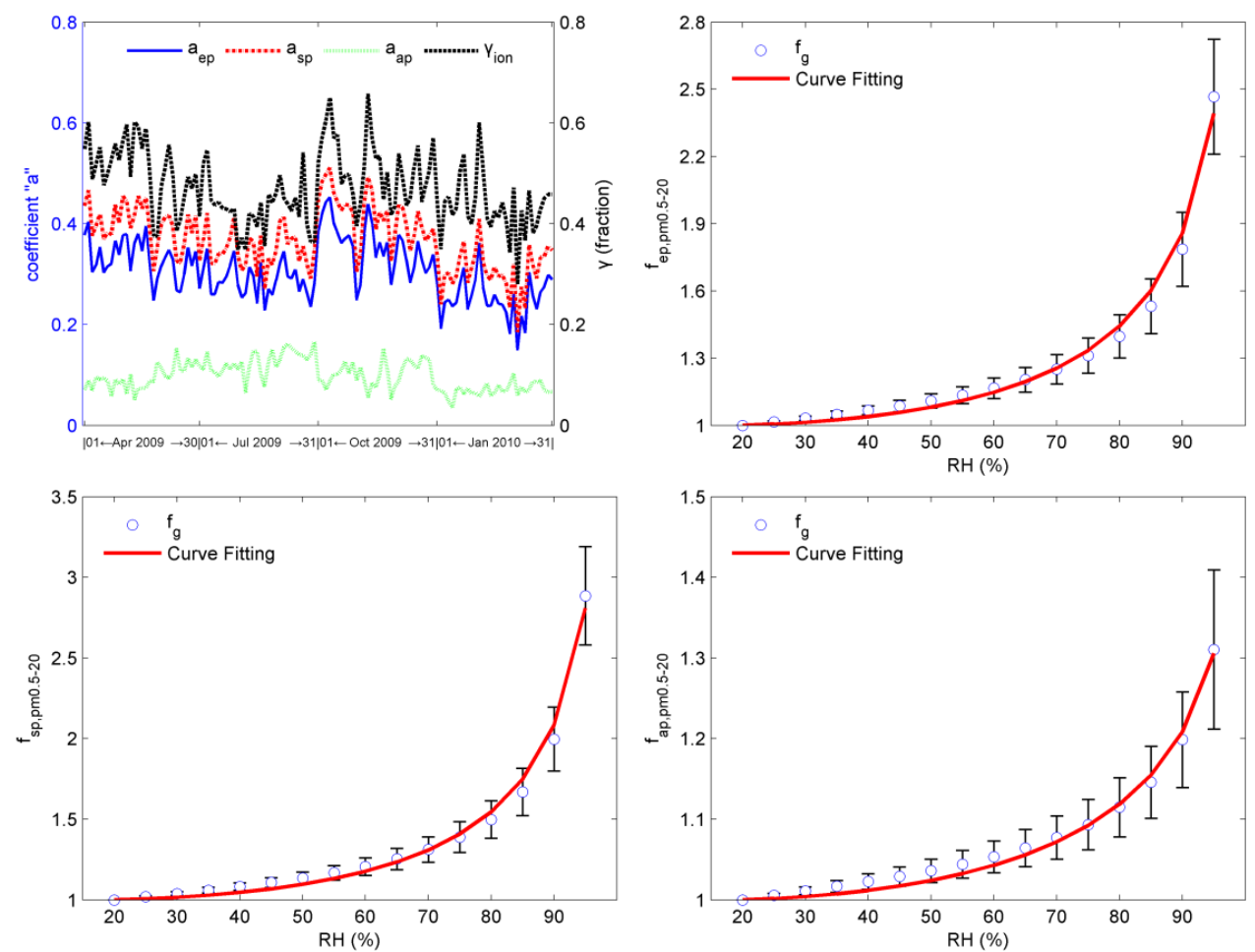

Fig. 7. Temporal variations of coefficient " $a$ " and the RH dependence curves of optical properties of $\mathrm{PM}_{0.5-20}$.

Table 5. Ambient RH condition and the corresponding chemical composition of $\mathrm{PM}_{2.5}$.

\begin{tabular}{lrrrr}
\hline Item & April & July & October & January \\
\hline $\mathrm{RH}($ in fraction) & 0.68 & 0.68 & 0.50 & 0.72 \\
$\mathrm{PM}_{2.5}\left(\mu \mathrm{g} \mathrm{m}^{-3}\right)$ & 94.8 & 44.6 & 95.4 & 130.8 \\
Inorganic species & $41 \%$ & $37 \%$ & $47 \%$ & $34 \%$ \\
$-\left(\mathrm{NH}_{4}\right)_{2} \mathrm{SO}_{4}$ & $15.5 \%$ & $10.4 \%$ & $24.8 \%$ & $10.9 \%$ \\
$-\mathrm{Na}_{2} \mathrm{SO}_{4}$ & $8.0 \%$ & $13.9 \%$ & $4.9 \%$ & $5.0 \%$ \\
$-\mathrm{NH}_{4} \mathrm{NO}_{3}$ & $5.8 \%$ & $0.3 \%$ & $0.3 \%$ & $7.1 \%$ \\
$-\mathrm{K}_{2} \mathrm{SO}_{4}$ & $2.4 \%$ & $1.4 \%$ & $2.6 \%$ & $1.8 \%$ \\
$-\mathrm{HNO}_{3}$ & $5.9 \%$ & $4.2 \%$ & $6.5 \%$ & $4.4 \%$ \\
$-\mathrm{NaHSO}_{4}$ & $0.1 \%$ & $1.2 \%$ & $3.0 \%$ & $0.0 \%$ \\
$-\mathrm{NH}_{4} \mathrm{Cl}$ & $0.6 \%$ & $0.1 \%$ & $0.0 \%$ & $1.2 \%$ \\
$\mathrm{H}_{2} \mathrm{O}$ & $31 \%$ & $26 \%$ & $19 \%$ & $29 \%$ \\
$\mathrm{POM}$ & $14 \%$ & $20 \%$ & $17 \%$ & $14 \%$ \\
EC & $6 \%$ & $8 \%$ & $7 \%$ & $6 \%$ \\
Residual & $8 \%$ & $10 \%$ & $9 \%$ & $17 \%$ \\
\hline
\end{tabular}

Under the assumption of "internal mixture", optical properties of $\mathrm{PM}_{0.5-20}$ were estimated with good accuracy by the Mie Model. The EORI, EGF and $\rho_{\text {dry }}$ were determined with an understanding of chemical composition of $\mathrm{PM}_{2.5}$; and particles number size distribution of $\mathrm{PM}_{0.5-20}$ was derived from APS. The monthly averages of them are summarised in Table 6 .
Table 6. Ambient RH condition and the corresponding optical properties of $\mathrm{PM}_{0.5-20}$.

\begin{tabular}{|c|c|c|c|c|}
\hline Item & April & July & October & January \\
\hline $\mathrm{RH}$ (in fraction) & 0.68 & 0.68 & 0.50 & 0.72 \\
\hline$n_{\mathrm{eff}}$ & 1.446 & 1.455 & 1.483 & 1.461 \\
\hline$k_{\text {eff }}$ & 0.034 & 0.041 & 0.040 & 0.032 \\
\hline$f_{\text {eff }}$ & 1.470 & 1.546 & 1.372 & 1.561 \\
\hline$\rho_{\text {dry }}\left(\mathrm{g} \mathrm{cm}^{-3}\right)$ & 1.78 & 1.93 & 1.87 & 1.80 \\
\hline$N\left(\right.$ particles $\left.\mathrm{cm}^{-3}\right)$ & 147.8 & 35.7 & 83.9 & 85.7 \\
\hline$b_{\mathrm{ep}}\left(\mathrm{Mm}^{-1}\right)$ & 300.0 & 78.6 & 146.9 & 188.5 \\
\hline$b_{\mathrm{sp}}\left(\mathrm{Mm}^{-1}\right)$ & 236.4 & 57.4 & 113.2 & 144.8 \\
\hline$b_{\text {ap }}\left(\mathrm{Mm}^{-1}\right)$ & 63.7 & 21.3 & 33.7 & 43.7 \\
\hline$f_{\mathrm{ep}}$ & 1.29 & 1.23 & 1.14 & 1.26 \\
\hline$f_{\mathrm{sp}}$ & 1.37 & 1.29 & 1.18 & 1.33 \\
\hline$f_{\text {ap }}$ & 1.07 & 1.10 & 1.04 & 1.05 \\
\hline$\omega^{\mathrm{a}}$ & 0.78 & 0.72 & 0.76 & 0.78 \\
\hline$\varphi^{\mathrm{b}}$ & 0.66 & 0.49 & 0.23 & 0.23 \\
\hline
\end{tabular}

a $\omega$ is ratio of $b_{\mathrm{sp}, \mathrm{pm} 0.5-20}$ to $b_{\mathrm{ep}, \mathrm{pm} 0.5-20}$.

${ }^{\mathrm{b}} \varphi$ is ratio of $b_{\mathrm{sp}, \mathrm{pm} 0.5-20}$ to $b_{\mathrm{sp}, \text { total }}$.

The highest average level of $b_{\text {ep }, \mathrm{pm} 0.5-20}$ being $300 \mathrm{Mm}^{-1}$ happened in April while the lowest one being $78.6 \mathrm{Mm}^{-1}$ in July. Regarding size distribution of $b_{\mathrm{ep}, \mathrm{pm} 0.5-20 \text {, peak }}$ value was almost located in the diameter range between 0.5 and $1.0 \mu \mathrm{m}$. Furthermore, hygroscopic growth of optical 
properties of $\mathrm{PM}_{0.5-20}$ largely depended on RH. As RH increased, $b_{\mathrm{ep}, \mathrm{pm} 0.5-20}$ grew and favoured a more rapid growth when aerosol had a high content of inorganic water-soluble salts. Averagely, $f_{\text {bep,pm0.5-20 }}$ enlarged 1.76 times when RH increased from $20 \%$ to $90 \%$. With regard to the temporal variation of ambient $\mathrm{RH}, f_{\text {bep,pm0.5-20 }}$ was $1.29,1.23,1.14$ and 1.26 on average in April, July, October and January, respectively.. Together with the measurement techniques and numerical models adopted currently, the SMPS-APS combination and the $\mathrm{PM}_{1.0} / \mathrm{PM}_{2.5} / \mathrm{PM}_{10}$ sampling will be deployed in near study for a further investigation on the impact of $\mathrm{RH}$ and particles number size distribution on estimating aerosol optical properties.

Acknowledgements. This work is supported by Commonwealth and Environmental Protection Project of the Ministry of Environmental Protection of the People's Republic of China (200809143); China National Basic Research and Development Program (2002CB410801 and 2011CB403403) and National Natural Science Foundation (41275017).

Edited by: S. C. Liu

\section{References}

Anderson, T. L. and Ogren, J. A.: Determining Aerosol Radiative Properties Using the TSI 3563 Integrating Nephelometer, Aerosol Sci. Tech., 29, 57-69, 1998.

Andreae, M. O., Schmid, O., Yang, H., Chand, D., Yu, J. Z., Zeng, L. M., and Zhang, Y. H.: Optical properties and chemical composition of the atmospheric aerosol in urban Guangzhou, China, Atmos. Environ., 42, 6335-6350, 2008.

Bergin, M., Hagler, G., Salmon, L., Zheng, M., Chameides, W., Kiang, C. S., Schauer, J., and Yu, J.: Fine particulate Matter $\mathrm{PM}_{2.5}$ in the Pearl River Delta. Project 2 Scientific Report to the Hong Kong Civic Exchange, 2004.

Bohren, C. F. and Huffman, D. R.: Absorption and scattering of light by small particles, John Wiley \& Sons, Inc., 1998.

Bond, T. C. and Bergstrom, R. W.: Light absorption by carbonaceous particles: an investigative review. Aerosol Sci. Tech., 40, 27-67, 2006.

Bougiatioti, A., Fountoukis, C., Kalivitis, N., Pandis, S. N., Nenes, A., and Mihalopoulos, N.: Cloud condensation nuclei measurements in the marine boundary layer of the Eastern Mediterranean: CCN closure and droplet growth kinetics, Atmos. Chem. Phys., 9, 7053-7066, doi:10.5194/acp-9-7053-2009, 2009.

Cao, J. J., Lee, S. C., Chow, J. C., Watson, J. G., Ho, K. F., Zhang, R. J., Jin, Z. D., Shen, Z. X., Chen, G. C., Kang, Y. M., Zou, S. C., Zhang, L. Z., Qi, S. H., Dai, M. H., Cheng, Y., and Hu, K.: Spatial and seasonal distributions of carbonaceous aerosols over China, J. Geophys. Res., 112, D22S11, doi:10.1029/2006JD008205, 2007.

Chazette, P. and Liousse, C.: A case study of optical and chemical ground apportionment for urban aerosols in Thessaloniki, Atmos. Environ., 35, 2497-2506, 2001.

Cheng, Y. F., Eichler, H., Wiedensohler, A., Heintzenberg, J., Zhang, Y. H., Hu, M., Herrmann, H., Zeng, L. M., Liu, S.,
Gnauk, T., Bruggemann, E., and He, L. Y.: Mixing state of elemental carbon and non-light-absorbing aerosol components derived from in situ particle optical properties at Xinken in Pearl River Delta of China, J. Geophys. Res., 111, D20204, doi:10.1029/2005JD006929, 2006.

Cheng, Y. F., Wiedensohler, A., Eichler, H., Su, H., Gnauk, T., Brüggemann, E., Herrmann, H., Heintzenberg, J., Slanina, J., Tuch, T., Hu, M., and Zhang, Y. H.: Aerosol optical properties and related chemical apportionment at Xinken in Pearl River Delta of China, Atmos. Environ., 42, 6351-6372, 2008a.

Cheng, Y. F., Wiedensohler, A., Eichler, H., Heintzenberg, J., Tesche, M., Ansmann, A., Wendisch, M., Su, H., Althausen, D., Herrmann, H., Gnauk, T., Bruggemann, E., Hu, M., and Zhang, Y. H.: Relative humidity dependence of aerosol optical properties and direct radiative forcing in the surface boundary layer at Xinken in Pearl River Delta of China: An observation based numerical study, Atmos. Environ., 42, 6373-6397, 2008b.

Cheng, Y. F., Zhang, Y. H., Hu, M., and Wiedensohler, A.: An observation-based method for investigating the atmospheric aerosol radiative properties in pearl river delta of China, http: //www.sciencep.com, China, 2008c.

Chow, J. C., Watson, J. G., Chen, L. W., Chang, M. C., Robinson, N. F., Trimble, D., and Kohl, S.: The IMPROVE_A temperature protocol for thermal/optical carbon analysis: maintaining consistency with a long-term database, J. Air Waste Manage., 57, 1014-1023, 2007.

Deng, X. J., Tie, X. X., Zhou, X. J., Wu, D., Zhong, L. J., Tan, H. B., Li, F., Huang, X. Y., Bi, X. Y., and Deng, T.: Effects of Southeast Asia biomass burning on aerosols and ozone concentrations over the Pearl River Delta (PRD) region, Atmos. Environ., 42, 84938501, 2008a.

Deng, X. J., Tie, X. X., Wu, D., Zhou, X. J., Bi, X. Y., Tan, H. B., Li, F., and Jiang, C. L.: Long-term trend of visibility and its characterizations in the Pearl River Delta (PRD) region, China, Atmos. Environ., 42, 1424-1435, 2008b.

Eichler, H., Cheng, Y. F., Birmili, W., Nowak, A., Wiedensohler, A., Brüggemann, E., Guauk, T., Herrmann, H., Althausen, D., Ansmann, A., Engelmann, R., Tesche, M., Wendisch, M., Zhang, Y. H., Hu, M., Liu, S., and Zeng, L. M.: Hygroscopic properties and extinction of aerosol particles at ambient relative humidity in South-Eastern China, Atmos. Environ., 42, 6321-6334, 2008.

Engelhart, G. J., Hildebrandt, L., Kostenidou, E., Mihalopoulos, N., Donahue, N. M., and Pandis, S. N.: Water content of aged aerosol, Atmos. Chem. Phys., 11, 911-920, doi:10.5194/acp-11911-2011, 2011.

Fan, S. J., Wang, B. M., Teshce, M., Engelmann, R., Althausen, A., Liu, J., Zhu, W., Fan, Q., Li, M. H., Ta, N., Song, L. L., and Leong, K. L.: Meteorological conditions and structures of atmospheric boundary layer in October 2004 over Pearl River Delta area, Atmos. Environ., 42, 6174-6186, 2008.

Fan, S. J., Fan, Q., Yu, W., Luo, X. Y., Wang, B. M., Song, L. L., and Leong, K. L.: Atmospheric boundary layer characteristics over the Pearl River Delta, China, during the summer of 2006: measurement and model results, Atmos. Chem. Phys., 11, 62976310, doi:10.5194/acp-11-6297-2011, 2011.

Fountoukis, C. and Nenes, A.: ISORROPIA II: a computationally efficient thermodynamic equilibrium model for $\mathrm{K}^{+}$$\mathrm{Ca}^{2+}-\mathrm{Mg}^{2+}-\mathrm{NH}_{4}^{+}-\mathrm{Na}^{+}-\mathrm{SO}_{4}^{2-}-\mathrm{NO}_{3}^{-}-\mathrm{Cl}^{-}-\mathrm{H}_{2} \mathrm{O}$ aerosols, Atmos. Chem. Phys., 7, 4639-4659, doi:10.5194/acp-7-4639-2007, 
2007.

Guauk, T., Muller, K., Pinxteren, D., He, L. Y., Niu, Y., Hu, M., and Herrmann, H.: Size-segregated particulate chemical composition in XinKen, Pearl River Delta, China: OC/EC and organic compounds, Atmos. Environ., 42, 6296-6309, 2008.

Gysel, M., Weingartner, E., Nyeki, S., Paulsen, D., Baltensperger, U., Galambos, I., and Kiss, G.: Hygroscopic properties of watersoluble matter and humic-like organics in atmospheric fine aerosol, Atmos. Chem. Phys., 4, 35-50, doi:10.5194/acp-4-352004, 2004.

Gysel, M., Crosier, J., Topping, D. O., Whitehead, J. D., Bower, K. N., Cubison, M. J., Williams, P. I., Flynn, M. J., McFiggans, G. B., and Coe, H.: Closure study between chemical composition and hygroscopic growth of aerosol particles during TORCH2, Atmos. Chem. Phys., 7, 6131-6144, doi:10.5194/acp-7-61312007, 2007.

Haynes, W. M. (Ed.): CRC Handbook of Chemistry and Physics 92 ${ }^{\text {nd }}$ Edition, CRC Press, 2011.

Jacobson, M. Z.: Strong radiative heating due to the mixing state of black carbon in atmospheric aerosol, Nature, 409, 695-697, 2001.

Jung, J. S., Lee, H., Kim, Y. J., Liu, X. G., Zhang, Y. H., Gu, J. W., and Fan, S. J.: Aerosol chemistry and the effect of aerosol water content on visibility impairment and radiative forcing in Guangzhou during the 2006 Pearl River Delta campaign, J. Environ. Manage., 90, 3231-3244, 2009.

Lesins, G., Chylek, P., and Lohman, U.: A study of internal and external mixing scenarios and its effect on aerosol optical properties and direct radiative forcing, J. Geophys. Res., 107, 4094, doi:10.1029/2001JD000973, 2002.

Liu, S., Hu, M., Slanina, S., He, L. Y., Niu, Y. W., Bruegemann, E., Gnauk, T., and Herrmann, H.: Size distribution and source analysis of ionic compositions of aerosols in polluted periods at Xinken in Pearl River Delta (PRD) of China, Atmos. Environ., 42, 6284-6295, 2008a.

Liu, X. G., Cheng, Y. F., Zhang, Y. H., Jung, J., Sugimoto, N., Chang, S. Y., Kim, Y. J., Fan, S. J., and Zeng, L. M.: Influences of relative humidity and particle chemical composition on aerosol scattering properties during the 2006 PRD campaign, Atmos. Environ., 42, 1525-1536, 2008 b.

Liu, X. G., Zhang, Y. H., Wen, M. T., Wang, J. L., Jung, J. S., Chang, S. Y., Hu, M., Zeng, L. M., and Kim, Y. J.: A Closure Study of Aerosol Hygroscopic Growth Factor during the PRD 2006 Campaign, Adv. Atmos. Sci., 27, 947-956, doi:10.1007/s00376-0099150-z, 2010.

Louie, P. K. K., Waston, J. G., and Chow, J. C.: Seasonal characteristics and regional transport of $\mathrm{PM}_{2.5}$ in Hong Kong, Atmos. Environ., 39, 1695-1710, 2005.

Seinfeld, J. H. and Pandis, S. N.: Atmospheric Chemistry and Physics: from air pollution to climate change (Second Edition), John Wiley \& Sons Inc., New York, 2006.

Shen, Z. X., Arimoto, R., Cao, J. J., Zhang, R. J., Li, X. X., Du, N., Tomoaki, O., Shunsuke, N., and Shigeru, T.: Seasonal variations and evidence for the effectiveness of pollution controls on watersoluble inorganic species in total suspended particulates and fine particulate matter from Xi' an, China, J. Air Waste Manage., 58, 1560-1570, 2008.

Shen, Z. X., Cao, J. J., Arimoto, R., Han, Z. W., Zhang, R. J., Han, Y. M., Liu, S. X., Okuda, T., Nakao, S., and Tanaka, S.: Ionic composition of TSP and $\mathrm{PM}_{2.5}$ during dust storms and air pollution episodes at Xi'an, China, Atmos. Environ., 43, 2911-2918, 2009.

Sloane, C. S.: Effect of composition on aerosol light scattering efficiencies, Atmos. Environ., 20, 1025-1037, 1986.

Stock, M., Cheng, Y. F., Birmili, W., Massling, A., Wehner, B., Müller, T., Leinert, S., Kalivitis, N., Mihalopoulos, N., and Wiedensohler, A.: Hygroscopic properties of atmospheric aerosol particles over the Eastern Mediterranean: implications for regional direct radiative forcing under clean and polluted conditions, Atmos. Chem. Phys., 11, 4251-4271, doi:10.5194/acp11-4251-2011, 2011.

Su, H., Cheng, Y. F., Cheng, P., Zhang, Y. H., Dong, S. F., Zeng, L. M., Wang, X. S., Slanina, J., Shao, M., and Wiedensohler, A.: Observation of nighttime nitrous acid (HONO) formation at a non-urban site during PRIDE-PRD2004 in China, Atmos. Environ., 42, 6219-6232, 2008.

Tang, I. N.: Chemical and size effects of hygroscopic aerosols on light scattering coefficients, J. Geophys. Res., 101, 1924519250, doi:10.1029/96JD03003, 1996.

Tao, J., Ho, K. F., Chen, L. G., Zhu, L. H., Han, J. L., and Xu, Z. C.: Effect of chemical composition of $\mathrm{PM}_{2.5}$ on visibility in Guangzhou, China, 2007 spring, Particuology, 7, 68-75, 2009.

Tie, X. X. and Cao, J. J.: Aerosol pollution in China: Present and future impact on environment, Particuology, 7, 426-431, 2009.

Wang, G., Li, J., Cheng, C., Hu, S., Xie, M., Gao, S., Zhou, B., Dai, W., Cao, J., and An, Z.: Observation of atmospheric aerosols at Mt. Hua and Mt. Tai in central and east China during spring 2009 - Part 1: EC, OC and inorganic ions, Atmos. Chem. Phys., 11, 4221-4235, doi:10.5194/acp-11-4221-2011, 2011.

Wang, T., Poon, C. N., Kwok, Y. H., and Li, Y. S.: Characterizing the temporal variability and emission patterns of pollution plumes in the Pearl River Delta of China, Atmos. Environ., 37, 3539-3550, 2003.

Wexler, A. S. and Clegg, S. L. Atmospheric aerosol models for systems including the ions $\mathrm{H}^{+}, \mathrm{NH}_{4}^{+}, \mathrm{Na}^{+}, \mathrm{SO}_{4}^{2-}$, $\mathrm{NO}_{3-}, \mathrm{Cl}^{-}, \mathrm{Br}^{-}$and $\mathrm{H}_{2} \mathrm{O}$, J. Geophys. Res., 107, 4207, doi:10.1029/2001JD000451, 2002.

Wu, D., Tie, X. X., Li, C. C., Ying, Z. M., Lau, A., Huang, J., Deng, X. J., and Bi, X. Y.: An extremely low visibility event over the Guangzhou region: a case study, Atmos. Environ., 39, 6568-6577, 2005.

Xiao, R., Takegawa, N., Zheng, M., Kondo, Y., Miyazaki, Y., Miyakawa, T., Hu, M., Shao, M., Zeng, L., Gong, Y., Lu, K., Deng, Z., Zhao, Y., and Zhang, Y. H.: Characterization and source apportionment of submicron aerosol with aerosol mass spectrometer during the PRIDE-PRD 2006 campaign, Atmos. Chem. Phys., 11, 6911-6929, doi:10.5194/acp-11-6911-2011, 2011.

Yu, H., Wu, C., Wu, D., and Yu, J. Z.: Size distributions of elemental carbon and its contribution to light extinction in urban and rural locations in the pearl river delta region, China, Atmos. Chem. Phys., 10, 5107-5119, doi:10.5194/acp-10-5107-2010, 2010.

Yue, D. L., Hu, M., Wu, Z. J., Guo, S., Wen, M. T., Nowak, A., Wehner, B., Wiedensohler, A., Takegawa, N., Kondo, Y., Wang, X. S., Li, Y. P., Zeng, L. M., and Zhang, Y. H.: Variation of particle number size distributions and chemical compositions at the urban and downwind regional sites in the Pearl River Delta during summertime pollution episodes, Atmos. Chem. Phys., 10, 
9431-9439, doi:10.5194/acp-10-9431-2010, 2010.

Zhang, Y. H., Hu, M., Zhong, L. J., Wiedensohler, A., Liu, S. C., Andreas, M. O., Wang, W., and Fan, S. J.: Regional integrated experiments on air quality over Pearl River Delta 2004 (PRIDEPRD2004): overview, Atmos. Environ., 42, 6157-6173, 2008a.
Zhang, Y. H., Su, H., Zhong, L. J., Cheng, Y. F., Zeng, L. M., Wang, X. S., Xiang, Y. R., Wang, J. L., Gao, D. F., Shao, M., Fan, S. J., and Liu, S. C.: Regional ozone pollution and observation-based approach for analyzing ozone-precursor relationship during the PRIDE-PRD 2004 campaign, Atmos. Environ., 42, 6203-6218, $2008 b$. 